\title{
Early Substance Use Initiation And Psychological Distress Among Adolescents In Five ASEAN Countries: A Cross-Sectional Study
}

This article was published in the following Dove Press journal: Psychology Research and Behavior Management

\author{
Supa Pengpid (1D ${ }^{1,2}$ \\ Karl Peltzer (D) ${ }^{2}$ \\ 'ASEAN Institute for Health \\ Development, Mahidol University, \\ Bangkok, Thailand; ${ }^{2}$ Deputy Vice \\ Chancellor Research and Innovation \\ Office, North-West University, \\ Potchefstroom, South Africa
}

Correspondence: Karl Peltzer Deputy Vice Chancellor Research and Innovation Office, North-West University, Potchefstroom Campus, II Hoffman Street, Potchefstroom 253I, South Africa

Tel +27 I8 2994927

Email kfpeltzer@gmail.com

\begin{abstract}
Aim: The study aimed to assess the associations between substance use early initiation $(<12$ years) (smoking cigarettes, alcohol and drug use) with psychological distress among adolescents in five ASEAN countries.

Methods: Cross-sectional data were analysed from 33,184 school adolescents, with a median age of 14 years, from Indonesia, Laos, Philippines, Thailand and Timor-Leste that took part in the "Global School-Based Student Health Survey (GSHS)" in 2015.

Results: The overall prevalence of pre-adolescent ( $<12$ years) cigarette use was $10.6 \%$, $8.1 \%$ pre-adolescent current alcohol use, and $4.2 \%$ pre-adolescent drug use initiation. In adjusted multinomial logistic regression analysis, pre-adolescent initiation of cigarette smoking, pre-adolescent initiation of alcohol use, pre-adolescent initiation of drug use and multi-substance pre-adolescent initiation were highly associated with medium $(=1)$ and high (=2-5) psychological distress (of five psychological distress items: no close friends, loneliness, anxiety, suicidal ideation and suicide attempt). Late initiation of cigarette use and late initiation of drug use were not associated with medium and/or high psychological distress.
\end{abstract}

Conclusion: Early prevention programmes should target concurrent early substance use initiation in order to prevent possible subsequent psychological distress.

Keywords: early substance use, psychological distress, adolescents, ASEAN countries

\section{Introduction}

During adolescence substance use, such as alcohol, tobacco, and illicit drugs, e.g., cannabis, is often initiated and a pattern of its use may become established. ${ }^{1}$ Studies mainly in high-income countries found that early substance use initiation is associated with substance use disorders, polysubstance use, and/or mental disorders, ${ }^{1-4}$ including suicidal behaviour. ${ }^{5}$ Therefore, the study aimed at investigating the association between early substance use initiation, polysubstance use and psychological distress among adolescents in five middle-income countries in ASEAN. The prevalence of current tobacco use among adolescents in ASEAN countries was $11-15 \%$ in Brunei, Indonesia, Malaysia, Thailand, and the Philippines, and the prevalence of current alcohol use was $16 \%$ to $24 \%$ in Thailand, Vietnam, and the Philippines. ${ }^{6}$ While the prevalence of lifetime cannabis and amphetamine use was $0.9 \%$ and $1.0 \%$, respectively, in Malaysia, and $0.6 \%$ and $0.2 \%$, respectively, in Vietnam. $^{7}$ 


\section{Methods}

\section{Sample And Procedure}

Cross-sectional data from the 2015 "Global School-Based Student Health Survey (GSHS)" of five ASEAN countries were analyzed. The GSHS uses a "cluster sampling design in two stages (schools and classrooms) in order to produce nationally representative samples of school children in middle schools." "Students completed a self-administered questionnaire under the supervision of trained survey administrators." "Country level ethics review boards approved the GSHS, and informed consent was obtained from the students, parents and/or school officials."

\section{Measures}

The GSHS measure questions that were used in this study are detailed in Table 1. "Early cigarette smoking, early drinking alcohol, and early drug use initiation were trichotomized into never, prior to 12 years, and 12 or more years."

Table I Variable Description

\begin{tabular}{|c|c|c|}
\hline Variables & Question & Response Options \\
\hline Age & "How old are you?" & II years old or younger to 18 years old or older \\
\hline Sex & "What is your sex?" & Male, female \\
\hline Hunger & $\begin{array}{l}\text { "During the past } 30 \text { days, how often did you go hungry } \\
\text { because there was not enough food in your home?" }\end{array}$ & $\begin{array}{l}\mathrm{I}=\text { never to } 5=\text { always (coded } \mathrm{I}-3=0 \text { and } 4-5=\mathrm{I} \text { : most of } \\
\text { the time or always) }\end{array}$ \\
\hline $\begin{array}{l}\text { Early cigarette use } \\
\text { initiation }\end{array}$ & "How old were you when you first tried a cigarette?" & $\begin{array}{l}\mathrm{I}=\mathrm{I} \text { have never smoked cigarettes; } 2=7 \text { years old or younger } \\
\text { to } 8=\mid 8 \text { years old or older (coded } \mathrm{I}=\text { never, } 2=2-4:<12 \\
\text { years, and } 3=5-8: 12-18 \text { years) }\end{array}$ \\
\hline $\begin{array}{l}\text { Early alcohol use } \\
\text { initiation }\end{array}$ & $\begin{array}{l}\text { "How old were you when you had your first drink of alcohol } \\
\text { other than a few sips?" }\end{array}$ & $\begin{array}{l}I=I \text { have never had a drink of alcohol other than a few sips; } \\
2=7 \text { years old or younger to } 8=18 \text { years old or older (coded } \\
I=\text { never, } 2=2-4:<12 \text { years, and } 3=5-8: I 2-18 \text { years) }\end{array}$ \\
\hline $\begin{array}{l}\text { Early drug use } \\
\text { Initiation }\end{array}$ & "How old were you when you first used drugs?" & $\begin{array}{l}I=I \text { have never used drugs; } 2=7 \text { years old or younger to } \\
8=I 8 \text { years old or older (coded } I=\text { never, } 2=2-4:<12 \text { years, } \\
\text { and } 3=5-8: 12-18 \text { years) }\end{array}$ \\
\hline $\begin{array}{l}\text { Current tobacco } \\
\text { use }\end{array}$ & $\begin{array}{l}\text { "During the past } 30 \text { days, on how many days did you smoke } \\
\text { cigarettes/use any tobacco products other than cigarettes, such } \\
\text { as pipes, roll your own cigarettes, or smokeless tobacco?" }\end{array}$ & $\begin{array}{l}I=0 \text { days to } 7=A l l 30 \text { days (coded } I=0 \text { and } 2-7=I \text { : at least } I \\
\text { or } 2 \text { days) }\end{array}$ \\
\hline Current alcohol use & $\begin{array}{l}\text { "During the past } 30 \text { days, on how many days did you have at } \\
\text { least one drink containing alcohol?" }\end{array}$ & $\begin{array}{l}I=0 \text { days to } 7=\text { All } 30 \text { days (coded } I=0 \text { and } 2-7=I \text { : at least } \\
I \text { or } 2 \text { days) }\end{array}$ \\
\hline Current cannabis use & $\begin{array}{l}\text { "During the past } 30 \text { days, how many times have you used } \\
\text { marijuana (also called ... country specific names)?" }\end{array}$ & $\begin{array}{l}\mathrm{I}=0 \text { times to } 5=20 \text { or more times (coded } \mathrm{I}=0 \text { and } 2-5=\mathrm{I} \text { : at } \\
\text { least } \mathrm{I} \text { or } 2 \text { times) }\end{array}$ \\
\hline Physically attacked & $\begin{array}{l}\text { "During the past } 12 \text { months, how many times were you } \\
\text { physically attacked?" }\end{array}$ & $\begin{array}{l}\mathrm{I}=0 \text { times to } 8=\mathrm{I} 2 \text { or more times ( } \operatorname{coded} \mathrm{I}=0 \text { and } 2-8=\mathrm{I}: \text { at } \\
\text { least once) }\end{array}$ \\
\hline In a physical fight & $\begin{array}{l}\text { "During the past } 12 \text { months, how many times were you in a } \\
\text { physical fight?" }\end{array}$ & $\begin{array}{l}\mathrm{I}=0 \text { times to } 8=\mathrm{I} 2 \text { or more times (coded } \mathrm{I}=0 \text { and } 2-8=\mathrm{I}: \text { at } \\
\text { least once) }\end{array}$ \\
\hline \multirow[t]{2}{*}{ Bullied } & "During the past 30 days, on how many days were you bullied?" & $\begin{array}{l}I=0 \text { days to } 7=\text { All } 30 \text { days (coded } I=0 \text { and } 2-7=I \text { : at least } I \\
\text { or } 2 \text { days) }\end{array}$ \\
\hline & Psychological distress & \\
\hline No close friends & "How many close friends do you have?" & $\mathrm{I}=0$ to $4=3$ or more $(\operatorname{coded} \mathrm{I}+=0,0=\mathrm{I})$ \\
\hline Anxiety & $\begin{array}{l}\text { "During the past } 12 \text { months, how often have you been so } \\
\text { worried about something that you could not sleep at night?" }\end{array}$ & $\mathrm{I}=$ never to $5=$ always $($ coded $\mathrm{I}-3=0$ and $4-5=\mathrm{I})$ \\
\hline
\end{tabular}

(Continued) 
Table I (Continued).

\begin{tabular}{|c|c|c|}
\hline Variables & Question & Response Options \\
\hline Loneliness & "During the past 12 months, how often have you felt lonely?" & $\mathrm{I}=$ never to $5=$ always $($ coded $\mathrm{I}-3=0$ and $4-5=\mathrm{I}$ ) \\
\hline Suicide ideation & $\begin{array}{l}\text { "During the past } 12 \text { months, did you ever seriously consider } \\
\text { attempting suicide?" }\end{array}$ & Yes, No \\
\hline Suicide attempt & $\begin{array}{l}\text { "During the past } 12 \text { months, how many times did you } \\
\text { actually attempt suicide?" }\end{array}$ & $\begin{array}{l}\mathrm{I}=0 \text { times to } 5=6 \text { or more times (coded } \mathrm{I}=0 \text { and } 2-5=\mathrm{I}: \mathrm{I} \\
\text { or more times) }\end{array}$ \\
\hline \multirow[t]{2}{*}{ Peer support } & $\begin{array}{l}\text { "During the past } 30 \text { days, how often were most of the } \\
\text { students in your school kind and helpful?" }\end{array}$ & $\mathrm{I}=$ never to $5=$ always $($ coded $\mathrm{I}-3=0$ and $4-5=\mathrm{I}$ ) \\
\hline & Parental support & \\
\hline Parental supervision & $\begin{array}{l}\text { "During the past } 30 \text { days, how often did your parents or } \\
\text { guardians check to see if your homework was done?" }\end{array}$ & $\mathrm{I}=$ never to $5=$ always $($ coded $\mathrm{I}-3=0$ and $4-5=\mathrm{I}$ ) \\
\hline $\begin{array}{l}\text { Parental } \\
\text { connectedness }\end{array}$ & $\begin{array}{l}\text { "During the past } 30 \text { days, how often did your parents or } \\
\text { guardians understand your problems and worries?" }\end{array}$ & $I=$ never to $5=$ always $($ coded $I-3=0$ and $4-5=I$ ) \\
\hline Parental bonding & $\begin{array}{l}\text { "During the past } 30 \text { days, how often did your parents or } \\
\text { guardians really know what you were doing with your free time? }\end{array}$ & $I=$ never to $5=$ always $($ coded $I-3=0$ and $4-5=I$ ) \\
\hline $\begin{array}{l}\text { Parental respect for } \\
\text { privacy }\end{array}$ & $\begin{array}{l}\text { "During the past } 30 \text { days, how often did your parents or } \\
\text { guardians go through your things without your approval?" }\end{array}$ & $I=$ never to $5=$ always $($ coded $I-3=0$ and $4-5=I$ ) \\
\hline
\end{tabular}

The psychological distress items (no close friends, loneliness, anxiety, suicidal ideation and suicide attempt) were summed, and grouped into $0=0$ low, $1=1$ medium and $2-5=2$ high. The four items on parental or guardian support were summed, and classified into three groups, 0-1 low, 2 medium and 3-4 high support. ${ }^{9}$

\section{Data Analysis}

Descriptive statistics were applied in order to present tabulations. Multinomial logistic regression was utilized to estimate the relative risk ratios (with $95 \%$ confidence interval $=\mathrm{CI}$ ) for medium and high psychological distress. Missing data were not included in the analysis. All statistical procedures were performed using "STATA software version 15.0 (Stata Corporation, College Station, TX, USA)", which took into account the complex survey design.

\section{Results}

\section{Characteristics Of The Sample}

The study sample included 33,184 middle school children, with a median age of 14 years (interquartile range $=2$ years) from Indonesia, Laos, Philippines, Thailand and Timor-Leste; the overall response rates ranged from $72 \%$ in Laos to $94 \%$ in Indonesia. ${ }^{6}$ The overall prevalence of pre-adolescent $(<12$ years) cigarette use was 10.6\%, 8.1\% pre-adolescent current alcohol use, and $4.2 \%$ pre-adolescent drug use initiation. There were country variations in the prevalence of pre-adolescent cigarette use, ranging from $3.3 \%$ in Laos to $11.0 \%$ in Indonesia and the Philippines, in the prevalence of pre-adolescent alcohol use, ranging from $3.9 \%$ in Indonesia to $14.1 \%$ in Timor-Leste, and in the prevalence of pre-adolescent drug use, ranging from $0.6 \%$ in Laos to $7.4 \%$ in the Philippines (see Table 2).

\section{Associations Of Substance Use Initiation With Medium And High Psychological Distress}

In adjusted multinomial logistic regression analysis, preadolescent initiation of cigarette smoking, pre-adolescent initiation of alcohol use, pre-adolescent initiation of drug use and multi-substance pre-adolescent initiation were highly associated with medium and high psychological distress. Late initiation of cigarette use and late initiation of drug use were not associated with medium and/or high psychological distress (see Table 3).

\section{Discussion}

The study found prevalences of pre-adolescent initiation of substance use, which seem lower than in previous studies, 
Table 2 Descriptive Characteristics Of Substance Use Initiation

\begin{tabular}{|c|c|c|c|c|c|c|c|c|c|c|c|c|}
\hline \multirow[t]{3}{*}{ Variable } & \multicolumn{3}{|c|}{ Onset Cigarette Smoking } & \multicolumn{3}{|c|}{ Onset Alcohol Use } & \multicolumn{3}{|c|}{ Onset Drug Use } & \multicolumn{3}{|c|}{$\begin{array}{l}\text { Early Substance } \\
\text { Use }\end{array}$} \\
\hline & Non-Initiators & $\begin{array}{l}<12 \\
\text { Years }\end{array}$ & $\begin{array}{l}12-18 \\
\text { Years }\end{array}$ & Non-Initiators & $\begin{array}{l}<12 \\
\text { Years }\end{array}$ & $\begin{array}{l}12-18 \\
\text { yrs }\end{array}$ & Non-Initiators & $\begin{array}{l}<12 \\
\text { Years }\end{array}$ & $\begin{array}{l}12-18 \\
\text { Years }\end{array}$ & 0 & 1 & $\begin{array}{l}2 \text { Or } \\
3\end{array}$ \\
\hline & $\%$ & $\%$ & $\%$ & $\%$ & $\%$ & $\%$ & $\%$ & $\%$ & $\%$ & $\%$ & $\%$ & $\%$ \\
\hline All $(\mathrm{N}=33,184)$ & 76.9 & 10.6 & 12.4 & 73.2 & 8.1 & 18.6 & 93.8 & 4.2 & 1.9 & 86.0 & 10.6 & 3.4 \\
\hline Indonesia (33.6\%) & 77.8 & 11.0 & 11.2 & 91.2 & 3.9 & 4.9 & 97.3 & 2.1 & 0.6 & 88.6 & 9.6 & 1.8 \\
\hline Laos (II.1\%) & 88.3 & 3.3 & 8.4 & 36.9 & 6.9 & 56.2 & 97.6 & 0.6 & 1.8 & 91.4 & 6.9 & 1.7 \\
\hline $\begin{array}{l}\text { Philippines } \\
(26.4 \%)\end{array}$ & 74.0 & 11.0 & 15.1 & 51.5 & 13.8 & 34.8 & 89.4 & 7.4 & 3.1 & 81.4 & 12.8 & 5.8 \\
\hline Thailand (17.8\%) & 78.9 & 9.4 & 11.7 & 55.3 & 12.1 & 32.6 & 90.1 & 5.5 & 4.4 & 85.0 & 10.2 & 4.9 \\
\hline $\begin{array}{l}\text { Timor-Leste } \\
\text { (II.2\%) }\end{array}$ & 66.7 & 9.9 & 23.4 & 70.2 & 14.1 & 15.7 & 90.4 & 7.0 & 2.6 & 83.9 & 11.0 & 5.0 \\
\hline Female (5I.1\%) & 91.1 & 4.1 & 4.8 & 78.6 & 5.7 & 15.8 & 96.4 & 2.7 & 0.9 & 92.8 & 5.5 & 1.7 \\
\hline Male (48.9\%) & 61.7 & 17.6 & 20.7 & 67.5 & 10.7 & 21.8 & 91.1 & 5.8 & 3.0 & 78.3 & 16.3 & 5.4 \\
\hline Hunger (5.2\%) & 70.1 & 12.3 & 17.6 & 66.0 & 12.1 & 21.9 & 87.4 & 8.4 & 4.1 & 80.9 & 14.1 & 5.0 \\
\hline $\begin{array}{l}\text { Current tobacco } \\
\text { use }(13.9 \%)\end{array}$ & 3.4 & 41.5 & 55.1 & 32.5 & 28.3 & 39.2 & 67.2 & 22.5 & 10.3 & 54.4 & 24.6 & 21.0 \\
\hline $\begin{array}{l}\text { Current alcohol } \\
\text { use }(12.5 \%)\end{array}$ & 41.6 & 25.0 & 33.3 & 0 & 33.3 & 66.7 & 71.2 & 18.5 & 10.3 & 60.7 & 20.3 & 19.1 \\
\hline $\begin{array}{l}\text { Current cannabis } \\
\text { use }(3.1 \%)\end{array}$ & 14.0 & 61.2 & 24.8 & 5.2 & 66.5 & 28.2 & 0 & 76.2 & 23.8 & 18.7 & 19.1 & 62.2 \\
\hline $\begin{array}{l}\text { Physically } \\
\text { attacked (33.1\%) }\end{array}$ & 66.8 & 16.7 & 16.5 & 65.6 & 13.1 & 21.4 & 89.1 & 8.2 & 2.8 & 78.6 & 14.5 & 6.9 \\
\hline $\begin{array}{l}\text { In physical fight } \\
(28.0 \%)\end{array}$ & 61.3 & 19.4 & 19.3 & 59.3 & 15.8 & 24.9 & 86.1 & 9.9 & 4.0 & 75.0 & 16.5 & 8.5 \\
\hline $\begin{array}{l}\text { Being bullied } \\
(30.6 \%)\end{array}$ & 70.2 & 15.4 & 14.4 & 60.3 & 15.3 & 24.5 & 87.8 & 9.2 & 3.0 & 78.4 & 14.3 & 7.3 \\
\hline \multicolumn{13}{|c|}{ Psychological distress } \\
\hline Low $(76.8 \%)$ & 80.9 & 7.7 & 11.4 & 79.6 & 4.6 & 15.8 & 97.4 & 1.3 & 1.3 & 89.3 & 9.3 & 1.4 \\
\hline Medium (14.6\%) & 72.6 & 14.3 & 13.1 & 62.0 & 13.4 & 24.6 & 88.4 & 8.7 & 2.8 & 80.8 & 12.9 & 6.4 \\
\hline High $(8.6 \%)$ & 62.6 & 17.9 & 19.4 & 46.8 & 20.3 & 32.9 & 84.5 & 11.3 & 4.3 & 73.7 & 16.5 & 9.8 \\
\hline $\begin{array}{l}\text { Peer support } \\
(36.8 \%)\end{array}$ & 80.5 & 8.1 & 11.4 & 77.3 & 5.2 & 17.6 & 89.1 & 9.0 & 1.8 & 86.0 & 5.8 & 8.1 \\
\hline \multicolumn{13}{|l|}{ Parental support } \\
\hline Low (51.6\%) & 71.8 & 13.4 & 14.8 & 67.7 & 10.6 & 21.7 & 91.2 & 6.4 & 2.4 & 82.9 & 12.1 & 5.0 \\
\hline Medium (27.0\%) & 80.1 & 8.6 & 11.3 & 76.7 & 6.0 & 17.3 & 96.5 & 1.8 & 1.7 & 87.9 & 10.1 & 2.0 \\
\hline High (21.4\%) & 86.0 & 5.8 & 8.1 & 82.7 & 4.1 & 13.2 & 98.1 & 0.9 & 1.0 & 91.4 & 7.5 & 1.1 \\
\hline
\end{tabular}

e.g., in four Pacific Island countries (15.7\% smoking; 13.8\% alcohol use, and $12.9 \%$ drug use), ${ }^{5}$ France (pre-teen cigarette initiation $24.1 \%$, pre-teen alcohol initiation $65.1 \%$ and pre-teen cannabis initiation 3.9\%), and the United States 
Table 3 Adjusted Prevalence Ratios For The Associations Of The Initiation Of Substance Use With Medium And High Psychological Distress

\begin{tabular}{|c|c|c|}
\hline Variable & $\begin{array}{l}\text { Medium } \\
\text { Psychological } \\
\text { Distress }\end{array}$ & $\begin{array}{l}\text { High } \\
\text { Psychological } \\
\text { Distress }\end{array}$ \\
\hline & $\operatorname{ARRR}(95 \% \mathrm{CI})^{\mathrm{a}}$ & $\operatorname{ARRR}(95 \% \mathrm{Cl})^{\mathrm{a}}$ \\
\hline $\begin{array}{l}\text { Initiation of } \\
\text { smoking cigarettes } \\
\text { Non-initiators } \\
<12 \text { years } \\
\geq 12 \text { years }\end{array}$ & $\begin{array}{l}\text { I (Reference) } \\
\text { I.5। }(1.29, \text { I.77) })^{* * *} \\
0.87(0.72,1.07)\end{array}$ & $\begin{array}{l}\text { I (Reference) } \\
2.46(2.04,2.98)^{* * *} \\
\text { I.64 }(1.30,2.07)^{* * *}\end{array}$ \\
\hline $\begin{array}{l}\text { Initiation of alcohol } \\
\text { use } \\
\text { Non-initiators } \\
<12 \text { years } \\
\geq 12 \text { years }\end{array}$ & $\begin{array}{l}\text { I (Reference) } \\
\text { I.92 (I.59, 2.3I)*** } \\
\text { I.24 (I.08, I.43)** }\end{array}$ & $\begin{array}{l}\text { I (Reference) } \\
3.05(2.48,3.75)^{* * *} \\
\text { I.73 }(1.46,2.06)^{* * *}\end{array}$ \\
\hline $\begin{array}{l}\text { Initiation of drug use } \\
\text { Non-initiators } \\
<12 \text { years } \\
\geq 12 \text { years }\end{array}$ & $\begin{array}{l}\text { I (Reference) } \\
2.68(2.04,3.53)^{* * *} \\
0.98(0.64,1.49)\end{array}$ & $\begin{array}{l}\text { I (Reference) } \\
2.0 \mathrm{I}(\mathrm{I} .3 \mathrm{I}, 3.08)^{* * *} \\
\mathrm{I} .07(0.77, \mathrm{I} .48)\end{array}$ \\
\hline $\begin{array}{l}\text { Initiation of } \\
\text { substance use } \\
0 \\
1 \\
2 \text { or } 3\end{array}$ & $\begin{array}{l}\text { I (Reference) } \\
\text { I.35 (I.I7, I.56)*** } \\
2.58(1.94,1.56)^{* * *}\end{array}$ & $\begin{array}{l}\text { I (Reference) } \\
\text { I.7I }(I .40,2.09)^{* * *} \\
3.23(2.39,4.38)^{* * *}\end{array}$ \\
\hline
\end{tabular}

Notes: adjusted for country, sex, age, socioeconomic status (hunger experience), current substance use, physically attacked, in physical fight, being bullied, peer and parental support; *** $\mathrm{P}<0.00 \mathrm{I}$; ** $\mathrm{P}<0.0 \mathrm{I}$.

Abbreviation: ARRR, adjusted relative risk ratio.

(pre-teen cigarette initiation $18.1 \%$, pre-teen alcohol initiation $27.7 \%$ and pre-teen cannabis initiation $9.7 \%$ ). ${ }^{10}$ The World Health Organziation ${ }^{11}$ notes that alcohol consumption in Southeast Asia is lower than in other regions of the world, and in particular, in Indonesia, a predominantly Muslim country, alcohol use may be lower because Islam prohibits the consumption of alcoholic beverages. ${ }^{12}$

The study confirmed previous findings, ${ }^{1-5}$ showing an association between early substance use initiation and psychological distress in this adolescent population in Southeast Asia. The correlations between psychological distress, illicit and licit use of drugs, such as alcohol and tobacco, may develop, because psychological problems and illicit and licit drug users may have common risk factors. ${ }^{13,14}$

\section{Study Limitations}

The study was cross-sectional, which precludes causal inferences. Drug use was measured by self-reporting and may have been underreported. Several study indicators were assessed with single items, and future studies should employ more comprehensive measures. The study did also not assess urban-rural residence, which should be included in future studies.

\section{Conclusion}

The study confirmed previous findings, showing an association between early substance use initiation and psychological distress in this adolescent population in Southeast Asia. Early prevention programmes should target concurrent early substance use initiation in order to prevent possible subsequent psychological distress.

\section{Acknowledgement}

The World Health Organization is acknowledged for making the datasets publicly available for this analysis.

\section{Disclosure}

The authors report no conflicts of interest in this work.

\section{References}

1. Hall WD, Patton G, Stockings E, et al. Why young people's substance use matters for global health. Lancet Psychiatry. 2016;3(3):265-279. doi:10.1016/S2215-0366(16)00013-4

2. Mathers M, Toumbourou JW, Catalano RF, Williams J, Patton GC. Consequences of youth tobacco use: a review of prospective behavioural studies. Addiction. 2006;101(7):948-958. doi:10.1111/j.13600443.2006.01438.x

3. Brownlie E, Beitchman JH, Chaim G, Wolfe DA, Rush B, Henderson J. Early adolescent substance use and mental health problems and service utilisation in a school-based sample. Can $J$ Psychiatry. 2019;64(2):116-125. doi:10.1177/0706743718784935

4. Roncero C, Palma-Álvarez RF, Barrau V, et al. Early cannabis use and its relation to the development of psychiatric disorders: a review. Salud Ment. 2017;40(6):291-298. doi:10.17711/SM.0185-3325.2017. 037

5. Peltzer K, Pengpid S. Early substance use initiation and suicide ideation and attempts among school-aged adolescents in four Pacific Island countries in Oceania. Int J Environ Res Public Health. 2015;12 (10):12291-12303. doi:10.3390/ijerph121012291

6. Hong SA, Peltzer K. Early adolescent patterns of alcohol and tobacco use in eight Association of South-East Asian Nations (ASEAN) member states. Subst Use Misuse. 2019;54(2):288-296. doi:10.1080/10 826084.2018.1517797

7. Peltzer K, Pengpid S. Cannabis and amphetamine use among adolescents in five Asian countries. Cent Asian J Glob Health. 2017;6 (1):288. eCollection 2017. doi:10.5195/cajgh.2017.288

8. World Health Organization (WHO). Global school-based student health survey (GSHS). 2019. Available from: https://www.who.int/ ncds/surveillance/gshs/en/. Accessed March 2, 2019

9. Pengpid S, Peltzer K. Leisure-time sedentary behavior is associated with psychological distress and substance use among school-going adolescents in five Southeast Asian countries: a cross-sectional study. Int J Environ Res Public Health. 2019;16:2091. doi:10.3390/ijerph 16122091 
10. Swahn MH, Bossarte RM, Choquet M, Hassler C, Falissard B, Chau N. Early substance use initiation and suicide ideation and attempts among students in France and the United States. Int J Public Health. 2012;57:95-105. doi:10.1007/s00038-011-0255-7

11. WHO. Alcohol Control Policies in the South-East Asia Region: Selected Issues. New Delhi, India: World Health Organization, Regional Office for South-East Asia; 2006.

12. Michalak L, Trocki K. Alcohol and Islam: an overview. Contemp Drug Prob. 2006;33(4):523-562. doi:10.1177/009145090603300401
13. Degenhardt L, Stockings E, Patton G, Hall WD, Lynskey M. The increasing global health priority of substance use in young people. Lancet Psychiatry. 2016;3(3):251-264. doi:10.1016/S2215-0366(15) 00508-8

14. Degenhardt L, Coffey C, Moran P, Carlin JB, Patton GC. The predictors and consequences of adolescent amphetamine use: findings from the victoria adolescent health cohort study. Addiction. 2007;102 (7):1076-1084. doi:10.1111/j.1360-0443.2007.01839.x

\section{Publish your work in this journal}

Psychology Research and Behavior Management is an international, peer-reviewed, open access journal focusing on the science of psychology and its application in behavior management to develop improved outcomes in the clinical, educational, sports and business arenas. Specific topics covered in the journal include: Neuroscience, memory and decision making; Behavior modification and management; Clinical applications; Business and sports performance management; Social and developmental studies; Animal studies. The manuscript management system is completely online and includes a very quick and fair peer-review system, which is all easy to use. Visit http://www. dovepress.com/testimonials.php to read real quotes from published authors. 